\title{
Chronic Fatigue Syndrome and Viral Infections
}

\author{
Frédéric Morinet ${ }^{1,{ }^{*}}$ and Emmanuelle Corruble ${ }^{2}$ \\ ${ }^{1}$ Hospital Saint-Louis, \\ Center of Innovative Therapy in Oncology and Hematology (CITOH),Paris, \\ ${ }^{2}$ Paris XI University, INSERM U 669, Department of Psychiatry, \\ Bicêtre University Hospital, Assistance Publique-Hôpitaux de Paris,
}

France

\section{Introduction}

The dream of all clinicians and researchers is to give their name to an illness, whatever the technique used to make the discovery. During the $20^{\text {th }}$ century and the early part of the $21^{\text {st }}$ century, several viruses have been identified by different procedures. Using electron microscopy, Epstein and Barr (Epstein et al., 1965) detected a Herpes virus in the lymphoid cells of a native African boy with a jaw tumor identified by the surgeon, Denis Burkitt (Burkitt, 1962). A few years later, using electrosyneresis, Blumberg detected the Hepatitis B antigen in the blood of an Australian aborigine (Blumberg et al., 1967, 1965). This immunological procedure was also used in 1975 by Yvonne Cossart to detect human parvovirus B19 in the serum of a blood donor in London (Cossart et al., 1975).

In the last decade, molecular biology techniques have prevailed for identifying new viruses. The viruses of Hepatitis C (Choo et al., 1989), Kaposi sarcoma (Chang et al., 1994) and Merkel carcinoma (Feng et al., 2008) have been detected in blood samples and skin biopsies. After detection, polymerase chain reaction (PCR) has been used routinely to identify pathogens. PCR is a specific and highly sensitive procedure. Its sensitivity explains the false positive results due to DNA contamination and great caution is required when positive PCR results are obtained.

There are several reasons why viral infections have long been suspected to be the cause of Chronic Fatigue Syndrome (CFS). Most patients report that their symptoms started suddenly with a flu-like illness. It is also known that some viruses, especially polio (an enterovirus), can produce a syndrome of permanent post-infection fatigue. Many people with CFS also have unusual immunological activity which might result from viral infections or predispose them to such infections. Nevertheless, at present the role of viruses in CFS remains unresolved, as it is for many autoimmune diseases such as type I diabetes and multiple sclerosis. If their precise etiological role remains elusive, despite their in vivo persistence, it seems that viruses may trigger the disease and then vanish. This mechanism, termed "hit and run", was described initially in bovine papillomatosis. Bovine papillomavirus is detected only at the initial stage of infection and never at the neoplastic stage (Favre, personal communication). Consequently, it may be that when a clinical diagnosis of CFS is made, it is too late to detect any possibly causative virus.

${ }^{*}$ Corresponding Author 
Finally, finding a viral etiology for CFS would open the door to specific therapy that would bring hope to patients.

After presenting a summary of CFS, we shall describe viral candidates and try, with the help of examples, to explore some possible mechanisms of virus infection.

\section{Background}

Interest in CFS increased in the early 1980s after an epidemic of neurological symptoms, referred to as "myalgic encephalomyelitis" (ME), occurred among the staff of a London hospital. Nowadays, CFS refers to the range of complaints found in ME, or chronic fatigue and immune dysfunction syndrome (Prins et al., 2006). CFS is characterized by persistent and unexplained fatigue, resulting in severe impairment of daily functioning.

\subsection{Definition of CFS}

The most widely supported scientific definition of CFS, which is now considered the standard, is that made in 1994 by the US Center for Disease Control and Prevention (Fukuda et al., 1994). In this definition, the illness is identified by the presence of subjective symptoms, disability and absence of other explanatory illnesses, and not by objective validators, such as physical signs or abnormalities detectable by laboratory tests or imaging techniques (Prins et al., 2006).

Criteria of CFS are the following:

- Persistent or relapsing unexplained chronic fatigue

- Fatigue lasting for at least 6 months

- Fatigue of new or definite onset

- Fatigue not resulting from an organic disease or from continuing exertion

- $\quad$ Fatigue not alleviated by rest

- Fatigue resulting in a substantial reduction in previous occupational, educational, social and personal activities

- Four or more of the following symptoms, concurrently present for 6 months: impaired memory or concentration, sore throat, tender cervical or axillary lymph nodes, muscle pain, pain in several joints, new headaches, non-refreshing sleep, or malaise after exertion

Are excluded:

- Medical condition explaining fatigue

- Major depressive disorder (psychotic features) or bipolar disorder

- Schizophrenia, dementia or delusional disorder

- Anorexia nervosa, bulimia nervosa

- Alcohol or substance abuse

- Severe obesity.

\subsection{Epidemiology and clinical signs}

The prevalence of CFS among adults ranges from $0.25 \%$ to $0.5 \%$, with higher rates in women $(75 \%)$ than men $(25 \%)$, and more frequent in people of lower educational attainment and 
occupational status. The estimated prevalence is lower among children and adolescents than in adults.

CFS begins generally in young adults. The main complaint is of a persistent, severe fatigue, frequently associated with pain (mainly myalgia and headache), cognitive dysfunction, and/or gastrointestinal problems. These symptoms result in substantial reduction in occupational, educational, social, and personal activities. A thorough history, a meticulous physical and mental status examination and a range of laboratory tests and an assessment of fatigue severity and functional impairment are needed to diagnose CFS.

Initially, CFS was compared with neurasthenia (Afari et al., 2003). Psychiatric comorbidities, especially depressive disorders, are commonly found (Afari et al., 2003; Choa et al., 2006).

Full recovery from CFS without treatment is rare. Poorer outcomes are predicted with psychiatric comorbidities and a better outcome may be predicted where there is a lower baseline fatigue (Prins et al., 2006).

\subsection{Etiology}

The potential roles of many somatic and psychosocial factors in the etiology of CFS have been explored (Prins et al., 2006), including: viral infections, immune dysfunction, neuroendocrine disorders, central nervous system dysfunction, muscle structure, exercise capacity, sleep patterns, genetics, personality, and neuropsychological processes. Both etiology and pathogenesis are probably multifactorial. To explain this complex disorder, interactions between predisposing, precipitating and perpetuating factors have been proposed.

Among predisposing factors, personality (neuroticism and introversion), lifestyle and genetics have been suggested. Among precipitating factors that might trigger the onset of CSF, acute physical stress, such as infection (flu-like illness, infectious mononucleosis, Q fever and Lyme disease), serious injuries, surgery, pregnancy, labor and psychological stress such as major life events have been cited.

\section{DNA viruses}

\subsection{Herpes virus}

The Herpes virus family includes DNA lymphotropic and neurotropic viruses. Epstein-Barr virus (EBV), Kaposi sarcoma virus (HHV-8) and cytomegalovirus (CMV) are lymphotropic whereas Herpes simplex virus (HSV), Varicella-zoster virus (VZV) and human Herpes virus 6 (HHV-6) are neurotropic. After an acute infection, these viruses persist in vivo and may reactivate during immunosuppression or after a stress. All, except EBV and HHV-8 are accessible to antiviral agents. For EBV and HHV- 8, reduction of immunosuppression seems to be sufficient.

\subsubsection{Herpes virus and disease}

There are two types of Herpes simplex virus: type 1 causes oral lesions whereas type 2 causes genital lesions. The skin lesions are typically vesicular. With the type 2 virus, the main problem is that if genital lesions occur during pregnancy, there is a risk of 
transmission to the neonate at delivery. With the type 1 virus, there is a risk of encephalitis, but this is very rare and depends on the patient's genetic background. Herpes simplex encephalitis is due to a series of monogenic primary immunodeficiencies that impair TLR3 and UNC-93B-dependent production of INF-alpha/beta and Interferon lambda in the central nervous system, at least in a small number of children (Sancho-Shimizu et al., 2007). Consequently, it would seem that treatment of Herpes simplex encephalitis with INF-alpha, as well as with acyclovir, could improve prognosis. Encephalitis may also occur during infection by HHV-6, principally in immunocompromised patients. With lymphotropic viruses, the clinical signs are essentially seen in immunodeficient patients, such as organ transplant and bone marrow recipients and HIV patients. EBV induces lymphoma, HHV-8 is the viral agent of Kaposi sarcoma and lymphoma, and CMV is the agent of interstitial pneumonia and retinitis.

\subsubsection{Herpes virus and CFS}

Herpes virus is a popular hypothetical candidate for the pathogenesis of CFS, either by primary infection or after the reactivation of a latent infection. Two Herpes viruses, EBV and $\mathrm{HHV}-6$, are suspected of playing a role in the development of CFS.

Prospective cohort studies have suggested that acute EBV infection triggers a post-infective syndrome in approximately $10 \%$ of patients, when evaluated 6 months after onset. Nevertheless, in a pilot study, serological patterns of anti-EBV antibody in the patients with CFS were not different from those who recovered promptly (Cameron et al., 2010). In addition, the levels of circulating EBV DNA were within the range found in healthy blood donors. Finally, in a double-blind, placebo-controlled study, acyclovir therapy in patients with CFS and persistent EBV antibodies did not improve CFS (Strauss et al., 1988). These findings must, however, be interpreted carefully since using acyclovir to treat EBV infection is questionable (personal data). In another study, valgancyclovir, an oral pro-drug of ganciclovir, was used to treat CFS patients with high EBV antibody titers (Kogelnik et al., 2006; Lerner et al., 2001). Clinical improvement was observed with a decrease in EBV antibody titer. These findings must be confirmed, but we cannot exclude the possibility that the drug has an immunomodulatory effect. Indeed, like acyclovir, valgancyclovir is not an ideal drug to treat EBV reactivation.

Because HHV-6 causes a life-long, ineradicable infection, and because of its broad tissue tropism, it has been reasonable to speculate that it might be a trigger and perpetuating factor for CFS (Komaroff, 2006). The similarities between CFS and several neurological diseases associated with HHV-6 have reinforced this speculation. In post-transplant patients, HHV-6 in the CNS causes cognitive dysfunction and fatigue similar to that reported by CFS patients. Human HHV-6 isolates are classified into two variants, termed HHV-6A (neurotropic) and HHV-6B, on the basis of their distinct genetic, antigenic and biological characteristics, but the specific pathogenicity of each variant remains poorly understood. Yalcin detected equal frequencies of HHV-6A and HHV-6B in 13 patients with CFS (Yalcin et al., 1994).

Clinical studies with antiviral drugs that have in vitro activity against HHV-6 (for example foscarnet) could provide strong evidence for, or against, any link between HHV-6 infection and development of CFS. 


\subsection{Parvovirus}

Autonomous parvoviruses, known to infect man, comprise parvovirus B19 and the recently discovered PARV4 and human bocavirus. PARV4 was originally detected in plasma from a patient with an "acute infection syndrome" resembling that of primary human immunodeficiency virus (HIV) infection. PARV4 is known to be widespread, specifically in people with a history of parenteral exposure (injecting drug users, hemophiliacs, polytransfused patients), with a strikingly higher incidence amongst those infected with HIV. Human bocavirus was originally found in the respiratory tracts of young children. Although it is frequently detected by PCR in the nasopharynx of viremic patients with primary lower respiratory tract infections, other co-infecting respiratory viruses are frequently detected (Servant et al., 2010). As far we know, only parvovirus B19 is involved in CFS.

\subsubsection{Parvovirus B19 and disease}

Discovered in 1975 (Cossart et al.,1975), B19 can cause a wide range of mild and selflimiting clinical signs, such as erythema infectiosum (fifth disease) and oligoarthritis (Servant et al., 2010). B19V infection may also cause acute anemia due to aplastic crisis in patients with shortened red cell survival and the chronic anemia of immunocompromised patients, i.e. HIV patients and those with congenital immunodeficiency, undergoing chemotherapy for malignancies or after organ transplant. It may also result in hydrops fetalis or fetal death. Erythroid progenitor cells are specifically targeted through expression of globoside $\mathrm{P}$ antigen, which acts as the receptor for B19 virus, explaining the development of anemia. Recently, cases of neurological signs and myocardial infections have been associated with B19 infection and the spectrum of B19-linked diseases may increase further. The primary route of $\mathrm{B} 19 \mathrm{~V}$ transmission is the respiratory tract (via aerosols), with a majority of infections occurring during childhood. The infection may also be transmitted by organ transplant and especially by transfusion of blood components, in particular packed red cells from blood collected during the short pre-seroconversion viremic phase. In classical natural history, an acute B19V infection occurring in immunologically competent individuals is controlled by neutralizing antibodies. A transient, high level viremia lasts for less than one week and declines with the appearance of specific IgM antibodies, which persist for eight to ten weeks, followed by the appearance of life-long specific IgG antibodies. Persistent infection may be observed in immunocompromised patients unable to produce neutralizing antibodies able to clear the virus, leading to chronic B19V carriage with or without anemia. In this case, an infusion of immunoglobulins is necessary. However, even if the immune response of healthy subjects is able to clear infection and provide life-long protection against $\mathrm{B} 19 \mathrm{~V}$, persistence of infection has been reported in the bone marrow of immunocompetent subjects with or without symptoms, and recently persisting low levels of B19V DNA were found in the blood of some immunocompetent subjects several years after primary infection. The mechanism of such chronic B19V carriage remains unclear.

\subsubsection{Parvovirus B19 and CFS}

McGhee (McGhee et al., 2005) reported the case of a 16-year-old boy with no evidence of immunodeficiency who had a 2-year history of chronic fatigue, low-grade fever and slapped-cheek rash associated with a chronic parvovirus B19 viremia that was detected by 
quantitative PCR. Parvovirus B19 titers for IgG and IgM were strongly positive. Three months of high dose (total $560 \mathrm{~g}$ ) intravenous immunoglobulin (IVIG) was required before both symptoms and viremia resolved. Slapped-check rash is not included in the diagnostic criteria of CFS, so in this case we must speak of chronic fatigue rather than CFS. It is not known whether his improvement and that of other patients described in the literature by Kerr et al. results from increased titers of specific antibody or is due to the immunomodulatory effects of high dose IVIG (Kerr et al., 2003). Whatever the mechanism, it seems that IVIG is a promising treatment for the chronic fatigue following Parvovirus B19 infection. Kerr (Denavur \& Kerr, 2006) claimed that acute symptomatic parvovirus B19 infection is associated with elevated circulating TNF-alpha and IFN-gamma and may be followed by CFS. Nevertheless Barbara Cameron, by analyzing serum cytokine levels in post-infective fatigue syndrome patients and in healthy controls, found no statistically significant differences in serum levels of any cytokines at any time (Cameron et al., 2010).

\subsection{Other DNA viruses}

Two other DNA viruses have been unsuccessfully associated to CFS. Firstly, the human polyomavirus JC which causes progressive multifocal leukoencephalopathy, and which infects granule cell neurons in the cerebellum and sometimes infects grey matter. It may also cause meningitis (Tan \& Koralnik, 2010). JC virus-induced disorders are essentially observed in immunosuppressed patients, whether or not HIV positive. There is no specific antiviral drug against the JC virus and the goal of current treatment is to restore the host's adaptive immune response to the JC virus so as to control infection. At present, there is no proof that JC virus induces CFS. The second virus putatively associated with CFS is a circovirus, the TTvirus. Circoviruses have a questionable pathogenicity in man, but in animals they may infect the brain and cause disease, e.g., post-weaning multisystemic wasting syndrome of pigs (Hino, 2002). Only one report suggests that TTvirus may induce CFS (Grinde, 2008). Further studies are necessary to implicate TTvirus, a non-pathogenic virus, in this syndrome.

\section{RNA viruses}

\subsection{Enterovirus}

Infection by enterovirus in man, although often asymptomatic, is responsible for a wide range of acute diseases (Morinet, 2008). In addition, they are possibly involved in the genesis of chronic enterovirus diseases, including chronic myocardial diseases, postpoliomyelitis syndrome and even juvenile-onset (type1) diabetes mellitus (see below). The role of enteroviruses in the pathogenesis of CFS, an old saga, has been largely disputed The detection, over a long period of time, of enterovirus structural proteins (VP-1 in sera) and enterovirus RNA in the muscle biopsy specimens of patients with CFS is disturbing (Douche-Aourik, 2003). Gow (Gow et al., 1994) investigated a large number of muscle biopsies from patients with either CFS or neuromuscular disorders and demonstrated the presence of enteroviral RNA by RT-PCR in $26.4 \%$ and $19.8 \%$ of samples respectively. It is necessary to demonstrate enterovirus within the muscle fibres by in situ PCR to prove that viral persistence alters the metabolism of the cells and thus show that such abnormalities cause clinical symptoms (Dalakas, 2003). 


\subsection{Other RNA viruses}

A case report recently described an adolescent boy who was diagnosed as suffering from CFS five months after infection with H1N1 influenza (Vallings, 2010). Laboratory test results were normal. Other articles investigated the role of GB virus in CFS (Jones et al., 2005; Sullivan et al., 2011). GB virus, a flavivirus, has many properties that require study to assess its possible association with CFS; effectively this virus replicates preferentially in peripheral blood mononuclear cells, primarily $\mathrm{B}$ and $\mathrm{T}$ lymphocytes, and in bone marrow in vivo. Nevertheless, two of twelve CFS patients and one of 21 healthy controls were seropositive for GB virus; consequently there is no evidence this virus is associated with CFS.

Among RNA viruses, there have been conflicting findings with the neurotropic, negativestranded RNA Borna virus (De la Torre, 2002). This virus is the causative agent of Borna disease, a sporadic and often fatal neurological disease of horses and sheep in central Europe and which has been known since the $18^{\text {th }}$ century (Schwemmle, 2001). The mode of transmission is unknown but is thought to be by saliva, or nasal and conjunctival secretions. Serological and molecular epidemiological studies suggest that such a virus can infect man (Nowotny \& Kolodziejek, 2000). Despite enormous efforts from many laboratories, it is still unclear whether Borna virus infection is associated with human psychiatric disease and CFS. Inadvertent sample contamination has been suggested (Durrwald et al., 2007; Schwemmle 2001; Evengard et al., 1999).

Finally, two studies have reported that most CFS patients harbour a gamma retrovirus, the xenotropic murine leukemia-related virus (XMRV) in blood (Kearney \& Maldarelli, 2010; Lombardi et al., 2009). This finding has raised speculation that it may cause the syndrome. However, four other laboratories could not replicate this finding, whilst four new studies found it only as a laboratory contaminant (Calaway, 2011; Cohen, 2011; Kaiser, 2011; Schutzer et al., 2011; Shin et al., 2011; Kean, 2010; Mayor, 2010; Sato et al., 2010; Stoye et al.,2010; Coffin \& Stoye, 2009). In 2011, at a retrovirology meeting in Boston, Massachusetts, researchers presented evidence that this retrovirus is, in effect, a laboratory artefact and not a human pathogen.

\section{Viral persistence}

A virus must have two essential characteristics in order to persist in a host (De la Torre et al., 1991). Firstly, the virus, by any one of several means, must escape the host's immunological surveillance. One classical mechanism is virus-induced down-regulation of HLA class I. The infected cell becomes invisible to TCD8+ cytotoxic lymphocytes. This mechanism is used extensively by Herpes viruses. The Herpes virus group is unique in that virtually all people have latent infections in their peripheral ganglia and/or their white blood cells, which may be reactivated to cause symptomatic disease, even decades after initial infection. One such virus, the Varicella Zoster Virus, induces shingles (zoster) many years after varicella infection in infancy. Virtually all the symptoms of shingles occur also in CFS, except for the painful rash (Shapiro, 2009). Secondly, the virus must generate defective particles and variants that diminish the expression of its gene product. For example the measles virus, after a primary infection, causes systemic disease with a typical skin rash. But during its replication it produces defective particles which persist in the CNS where their accumulation may lead to subacute sclerosing panencephalitis after ten years. This disease is prevented by measles vaccination. 
Another mechanism by which persistent virus infection produced disease was uncovered after the discovery that some viruses could alter cell differentiation (i.e. the "luxury" function of cells), without causing cell destruction, and thereby altering homeostasis. For example, whilst examining the effects of persistent lymphocytic choriomeningitis virus (an RNA virus which infects mice) infection on differentiated neuroblastoma cells, Oldstone (Oldstone et al., 1982) noted abnormalities in the synthesis and degradation of the neurotransmitter acetylcholine caused by decreased production of the appropriate acetylase or esterase enzyme. Nevertheless, these neuroblastoma cells were of normal morphology, growth rate, cloning efficiency and in levels of total RNA, DNA, protein and vital enzyme synthesis. Infected cells were indistinguishable from infected ones by both light and high resolution electromicroscopy. In man, after infection with influenza virus, peripheral blood lymphocytes no longer performed their expected specialized functions, including antibody synthesis and they no longer had the capacity to act as killer cells (Oldstone, 2002). Hence, this human RNA virus altered the different cell functions without lysing or destroying them. Viruses act very subtly on a cell and disorder its function, but not so severely as to kill the infected cell. Yet, for the host, the end result is perturbed homeostasis and disease.

Persistent enterovirus infections have been implicated in a number of chronic human diseases including dilated cardiomyopathy, chronic muscle disorders, type I diabetes mellitus and myalgia encephalomyelitis/CFS. Chia (Chia et al., 2010) demonstrated the presence of enterovirus protein, viral RNA and the replication of non-cytopathic viruses from stomach biopsies from CFS patients, years after the initial acute flu-like illness. More interestingly, in a prospective, longitudinal study of three patients, all developed acute enterovirus infections, documented by the presence of enteroviral RNA in the secretions, blood or affected tissues, and, over the next few years, this was followed by a range of symptoms consistent with CFS. Years after acute infections with respiratory/gastrointestinal symptoms, viral protein and RNA were found in stomach biopsies. Chronic infections in immunocompetent hosts may represent stalemate between attenuated, intracellular viruses and an ineffective immune response.

\section{Hit and run}

Over the past twenty years, no study has found conclusive evidence of an infectious etiological agent for CFS. The disorder is complex and multifactorial; nevertheless we cannot exclude the possibility that some infectious agent may trigger the disorder and then vanish. This mechanism, termed "hit and run" is well known in virology. In vitro, B cell cancers tend to maintain gammaherpesvirus genomes, whereas Kaposi's sarcoma and nasopharyngeal carcinoma tend to lose them (Stevenson et al., 2010). In bovine papillomatosis, at the stage of in situ carcinoma, viral sequences are no longer detected. It also seems that the HTLV-1 Tax protein is absent at the final step of leukemia/lymphoma. Outside the field of oncology, paramyxovirus and respiratory viruses exhibit a "hit and run" phenomenon indicated by the development of asthmatic symptoms long after the infection has cleared (Holtzman et al., 2004). A single paramyxoviral infection of mice (C57BL6/J strain) not only produces acute bronchiolitis but also triggers a chronic response with airway hyper-reactivity and goblet cell hyperplasia lasting for at least a year after complete viral clearance (Walter et al., 2002). A "hit and run" event may also occur where antibodies to a virus recognize similar amino-acid sequences or patterns found in host cells. This cross-reactivity is termed molecular mimicry 
and does not require a replicating agent, and an immune mediated injury may occur after the immunogen has been removed (Oldstone, 1998).

\section{Conclusion}

CFS is a common problem and all clues as to its possible cause are welcome. Despite intense efforts, no virus has been clearly incriminated. Their detection seems more casual that causal. In addition, the study of viral infections in monozygotic twins who are discordant for CFS does not suggest that a virus is the culprit (Koelle et al., 2002). The recent association of XMRV with CFS re-opens the debate about laboratory contamination; whether the detection of this gammaretrovirus indicates a real infection or whether it is due to a laboratory artefact remains highly controversial. If the findings linking XMRV with CFS are not due to laboratory artefacts, how can we explain the failure of other investigators to replicate the findings? Different inclusion criteria for CFS cannot account for the difference between $0 \%$ and $67 \%$ found in the laboratories (Weiss, 2010).

One over-arching question is the following: is CFS an infectious disease? If this is the case, despite the absence of supporting data, patients with CFS must abstain from blood donation, as has been suggested by Bridget M. Kuehn (Kuehn, 2010) in a provocative editorial of the JAMA. At present, there has been no confirmation that transfusion is associated with the disease.

\section{References}

Afari N.\&Buchwald D (2003).Chronic Fatigue Syndrome: A Review. Am J Psychiatry, Vol. $160,221-236$.

Blumberg BS., Gerstley BJ., Hungerford DA., London WT. \& Sutnick AI.(1967) A serum antigen (Australia antigen) in Down's syndrome, leukemia and hepatitis. Ann Intern Med, Vol. 66, 924-931

Blumberg BS., Alter HJ. \& Vinisch SA.(1965) A “new antigen in leukemia sera. JAMA, Vol. 191, 541-546

Burkitt D. (1962) A children's cancer dependent on climatic factors. Nature, Vol. 194, 232-234

Callaway E. (2011) Fighting For A Cause. Nature, Vol. 471, 282-285

Cameron B., Flamand L., Juwana H., Middeldorp J., Naing Z., Rawlinson W., Ablashi D. \& Lloyd A. (2010) Serological and Virological Investigation of the Role of the Herpesviruses EBV, CMV and HHV-6 in Post-Infective Fatigue Syndrome., J Med Virol., Vol. 82, 1684-1688

Cameron B., Hirschberg DL., Rosenberg-Hassan Y., Ablashi D. \& Lloyd A. (2010) Serum Cytokine Levels in Postinfective Fatigue Syndrome. CID, Vol. 50,

Chang Y., Cesarman E., Pessin MS., Lee F., Culpepper J., Knowles DM. \& Moore P. (1994) Identification of Herpesvirus-Like DNA Sequences in AIDS-Associated Kaposi' Sarcoma. Science, Vol. 266,1865-1869

Chia J., Chia A., Voeller M., Lee T. \& Chang R. (2010) Acute enterovirus infection followed by myalgic encephalomyelitis/chronic fatigue syndrome(ME/CFS) and viral persistence. J.Clin.Pathol., Vol. 63, 165-168 
Choa HJ., Skowerab A., Clearea A. \& Wesselya S. (2006). Chronic fatigue syndrome: an update focusing on phenomenology and pathophysiology. Curr Opin Psychiatry, Vol. 19,67-73.

Choo QL., Kuo G., Weiner AJ., Overby LR., Bradley DW. \& Houghton M.(1989) Isolation of a cDNA Clone Derived from a Blood-Borne Non-A, Non-B Viral Hepatitis Genome. Science, Vol. 244, 360-362

Coffin JM. \& Stoye J. (2009) A New Virus for Old Diseases. Science, Vol. 326, 530-531, ISSN 0036-8075

Cohen J. (2011) More Negative Data for Link Between Mouse Virus and Human Disease. Science, Vol. 331, 1253-1254,ISSN 0036-8075

Cossart YE., Field AM., Cant B. \& Widdows D.(1975), Parvovirus-like particles in human sera. Lancet, Vol. 1 (7898), 72-73

Dalakas MC. (2003) Enteroviruses in chronic fatigue syndrome: "now you see them, now you don't". J.Neurol Neurosurg Psychiatry, Vol. 74,1361-1362

De La Torre (2002) Bornavirus and the Brain. JID, Vol. 186, S241-S247

De La Torre JC., Borrow P. \& Oldstone MBA.(1991) Viral persistence and disease: Cytopathology in the absence of cytolysis. British Medical Bulletin, Vol. 47, 838-851

Denavur LD. \& Kerr JR. (2006) Chronic fatigue syndrome. J Clin Virol., Vol. 37, 139-150

Douche-Aourik F., Berlier W., Féasson L., Bourlet T., Harrath R., Omar S., Grattard F., Denis C. \& Pozzetto B. (2003) Detection of Enterovirus in Human Skeletal Muscle From Patients With Chronic Inflammatory Muscle Disease or fibromyalgia and Healthy Subjects. J.Med.Virol., Vol. 71, 540-547

Durrwald R., Kolodziejek J., Herzog S. \& Nowotny N. (2007) Meta-analysis of putative human bornavirus sequences fails to provide evidence implicating Borna disease virus in mental illness. Rev.Med.Virol., Vol.17, 181-203

Epstein MA., Henle G., Achong BG \& Barr YM. (1965) Morphological and biological studies on a virus in culture lymphoblasts from Burkitt's lymphoma. J Exp Med, Vol. 121, 761-770

Evengard B., Briese T., Lindh G., Lee S. \& Lipkin WI. (1999)Absence of evidence of borna disease virus infection in Swedish patients with Chronic Fatigue Syndrome. J. NeuroVirol, Vol. 5, 495-499

Feng h., Shuda M., Chang Y. \& Moore P. (2008) Clonal Integration of a Polyomavirus in Human Merkel Cell Carcinoma. Science, Vol. 319,1096-1100

Fukuda K., Straus SE., Hickie I., Sharpe MC., Dobbins JG., Komaroff A. \& the International Chronic Fatigue Syndrome Study Group. The Chronic Fatigue Syndrome: A Comprehensive Approach to Its Definition and Study (1994). Ann Intern Med, Vol. 121, 953-959.

Gow JW., Behan WM., Simpson K., Mc Garry F., Keir S. \& Behan PO. (1994) Studies on enterovirus in patients with chronic fatigue. CID, Vol.18, S126-129.

Grinde B. (2008) Is chronic fatigue syndrome caused by a rare brain infection of a common, normally benign virus? Medical Hypotheses, Vol. 71, 270-274

Hino S. (2002) TTV, a new human virus with single stranded circular DNA genome. Rev Med. Virol, Vol. 12,151-158

Holtzman MJ., Shornick LP., Grayson MH., KimEY., Tyner JW., Patel AC., Agapov E. \& Zhang Y. (2004) «Hit-and-Run » effects of Paramyxoviruses as a basis for Chronic Respiratory Disease. Pediatr Infect Dis J, Vol. 23, S235-S245, ISSN 08913668/04/2311-0235 
Jones JF., Kulkarni PS., Butera ST, \& Reeves W. (2005) GB-virus-C- a virus without a disease: We cannot give it chronic fatigue syndrome. BMC Infectious Diseases, Vol. 5, 78

Kaiser, J. (2011) Studies Point to Possible Contamination in XMRV Findings. Science, Vol. 331, 17, ISSN 0036-8075

Kean S. (2010) An Indefatigable Debate Over Chronic Fatigue Syndrome. Science, Vol. 327, 254-255, ISSN 0036-8075

Kearney M. \& Maldarelli F. (2010) Current Status of Xenotropic Murine Leukemia VirusRelated Retrovirus in Chronic Fatigue Syndrome and Prostate Cancer: Reach for a Scorecard, Not a Prescription Pad. JID, Vol. 202, 1463-1466

Kerr JR., Cunniffe VS., Kelleher P., Bernstein RM., \& Bruce IN. (2003) Successful Intravenous Immunoglobulin Therapy in 3 Cases of Parvovirus B19-Associated Chronic Fatigue Syndrome. CID, Vol. 36,e100-6

Koelle DM., Barcy S., Huang ML., Ashley RL., Corey L., Zeh J., Ashton S \& Buchwald D. (2002) Markers of viral infection in monozygotic twins discordant for chronic fatigue syndrome. CID, 35, 518-525

Kogelnik AQM., Loomis K., Hoegh-Petersen M., Rosso F., Hischier C. \& Montoya JG. (2006) Use of valganciclovir in patients with elevated antibody titers against Human Herpesvirus6 (HHV-6) and Epstein-Barr Virus (EBV) who were experiencing central nervous system dysfunction including long-standing fatigue. J Clin Virol,Vol. 37, S33-S38

Komaroff AL. (2006) Is human herpesvirus-6 a trigger for chronic fatigue syndrome? J Clin Virol., Vol. 37, S39-S46

Kuehn BM. (2010) Study reignites debate about viral agent in patients with chronic fatigue syndrome. JAMA, Vol. 304,1653-1656

Lerner AM., Zervos M., Chang CH., Beqaj S., Goldstein J., O’Neill W., Dworkin H., Fitgerald T. \& Deeter RG. (2001) A Small, Randomized, Placebo-Controlled Trial of the Use of Antiviral Therapy for Patients with Chronic Fatigue Syndrome. CID, Vol. 32, 1657-1658

Lombardi VC., Ruscetti FW., Das Gupta J., Pfost MA., Hagen K., Peterson DL., Ruscetti SK., Bagni R.K., Petrow-Sadowski C., Gold B., Dean M., Silverman RH.\& Mikovits JA. (2009) Detection of an Infectious Retrovirus, XMRV, in Blood Cells of Patients With Chronic Fatigue Syndrome. Science, Vol. 326, 585-589, ISSN 0036-8075

Mayor S. (2010) Study fails to show link previously found between virus chronic fatigue syndrome. BMJ, Vol. 340, c1033

McGhee SA., Kaska B., Liebhaber M. \& Stiehm ER. (2005) Persistent Parvovirus-Associated Chronic Fatigue Treated with High Dose Intravenous Immunoglobulin. Pediatr Infect Dis J, Vol. 24, 3, 272-274

Morinet, F. (2008). Virus et muscles. Revue du Rhumatisme, Vol. 75, 169-171, ISSN 1169-8330

Nowotny N. \& Kolodziejek J. (2000) Demonstration of Borna Disease Virus Nucleic Acid in a patient with Chronic Fatigue Syndrome. JID, Vol. 181, 1860-1861

Oldstone,MBA.(2002) Travels along the viral-immunobiology highway., Immunologial Reviews, Vol. 185, 54-68

Oldstone, MBA. (1998). Molecular mimicry and immune-mediated diseases. FASEB J., Vol. 12, 1255-1265

Oldstone, MBA., Sinha Y.N., Blount P., Tishon A., Rodriguez M., Von Wedel R. \& Lampert PW. (1982) Virus-induced alterations in Homeostasis: Alterations in differentiated Functions of Infected Cells in vivo. Science, Vol. 218, 1125-1127 
Prins JB., van der Meer JWM. \& Bleijenberg G. (2006). Chronic fatigue syndrome. Lancet, Vol. 367, 346-355

Sancho-Shimizu V., Zhang SY., Abel L., Tardieu M., Rozenberg F., Jouanguy E. \& Casanova JL. (2007) Genetic susceptibility to herpes simplex virus 1 encephalitis in mice and humans. Curr Opin Allergy Clin Immunol, Vol. 7, 495-505

Sato E., Furuta RA. \& Miyazawa T. (2010) An Endogenous Murine Leukemia Viral genome Contaminant in a Commercial RT-PCR Kit is Amplified Using Standard Primers for XMRV. Retrovirology, Vol. 7, 110

Shapiro JS., (2009) Does varicella-zoster virus infection of the peripheral ganglia cause Chronic Fatigue Syndrome?, Medical Hypotheses, Vol. 73, 728-734

Schutzer S., Rounds MA., Natelson BH, Ecker DJ; \& Eshoo MW. (2011) Analysis of Cerebrospinal Fluid from Chronic Fatigue Syndrome Patients for Multiple Human Ubiquitous Viruses and Xenotropic Murine Leukemia-Related Virus. Ann Neurol,1-4

Schwemmle M.(2001) Borna disease virus infection in psychiatric patients: are we on the right track? Lancet Infectious Diseases, Vol. 1, 46-52

Servant-Delmas A., Lefrere JJ., Morinet F.\& Pillet S. (2010) Advances in Human B19 Erythrovirus Biology. J.Virol., Vol. 84, 19, 9658-9665

Shin $\mathrm{CH}$. , Bateman L., Schlaberg R., Bunker AM., Leonard CJ., Hughen RW., Light AR., Light KC. \& Singh IR. (2011) Absence of XMRV Retrovirus and Other Murine Leukemia Virus-Related Viruses in Patients with Chronic Fatigue Syndrome. J.Virol, Vol. 85, 14, 7195-7202

Stevenson PG., May JS., Connor V. \& Efstathiou S. (2010) Vaccination against a hit-and-run viral cancer. J.Gen.Virol.,Vol. 91, 2176-2185

Stoye JP., Silverman RH., Boucher CA. \& Le Grice SFJ. (2010) The xenotropic murine leukemia virus-related retrovirus debate continues at first international workshop. Retrovirology,Vol. 7, 113

Straus S., Dale JK., Tobi M., Lawley T., Preble O., Blaese RM., Hallahan C. \& Henle W. (1988) Acyclovir Treatment of the Chronic Fatigue Syndrome. N Engl J Med, Vol. 319, 1692-1698.

Sullivan PF., Allander T., Lysholm F., Goh S., Persson B., Jacks A., Evengard B., Pedersen NL. \& Andersson B. (2011) An unbiased metagenomic search for infectious agents using monozygotic twins discordant for chronic fatigue. BMC Microbiology, 11,2

Tan CS. \& Koralnik IJ. (2010) Progressive multifocal leukoencephalopathy and other disorders caused by JC virus: clinical features and pathogenesis. Lancet Neurol, Vol. 9, 425-437

Vallings R. (2010) A case of chronic fatigue syndrome triggered by influenza H1N1 (swine influenza). J.Clin.Pathol., Vol. 63, 184-185

Walter, MJ., Morton JD., Kajiwara N., Agapov E. \& Holtzman MJ. (2002) Viral induction of a chronic asthma phenotype and genetic segregation from the acute response. J.Clin.invest., Vol. 110, 165-175

Weiss RA.(2010) A cautionary tale of virus and disease. BMC Biology, 8, 124

Yalcin S., Kuratsune H., Yamaguchi K., Kitani T. \& Yamanishi K. (1994) Prevalence of human herpesvirus 6 variants A and B in patients with chronic fatigue syndrome Microbiol Immunol., Vol. 38, 7, 587-590 


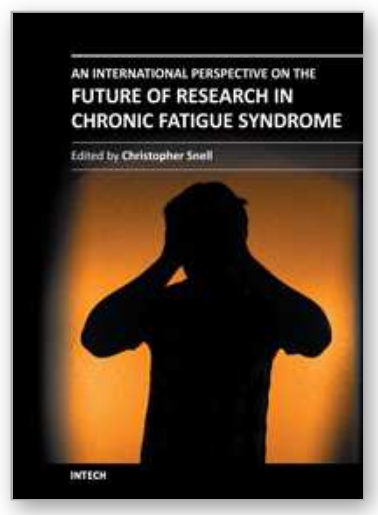

\author{
An International Perspective on the Future of Research in Chronic \\ Fatigue Syndrome \\ Edited by Dr. Christopher R. Snell
}

ISBN 978-953-51-0072-0

Hard cover, 104 pages

Publisher InTech

Published online 15, February, 2012

Published in print edition February, 2012

While the chapters in this book are a long way from solving the enigma that is CFS, they do represent important attempts to understand this complex and perplexing disease. A common theme in them all is CFS as a multisystem disease with the possibility of more than one cause and influenced by a variety of interacting factors. Further, they acknowledge the reality of CFS for persons with this disease and the importance of finding causes, treatments and ultimately a cure. As advanced biomedical research techniques are increasingly applied to the study of CFS, it is surely only a matter of time before biomarkers are identified, etiologies understood, and remedies devised.

\title{
How to reference
}

In order to correctly reference this scholarly work, feel free to copy and paste the following:

Frédéric Morinet and Emmanuelle Corruble (2012). Chronic Fatigue Syndrome and Viral Infections, An International Perspective on the Future of Research in Chronic Fatigue Syndrome, Dr. Christopher R. Snell (Ed.), ISBN: 978-953-51-0072-0, InTech, Available from: http://www.intechopen.com/books/an-internationalperspective-on-the-future-of-research-in-chronic-fatigue-syndrome/chronic-fatigue-syndrome-and-viralinfections

\section{INTECH}

open science | open minds

\section{InTech Europe}

University Campus STeP Ri

Slavka Krautzeka 83/A

51000 Rijeka, Croatia

Phone: +385 (51) 770447

Fax: +385 (51) 686166

www.intechopen.com

\section{InTech China}

Unit 405, Office Block, Hotel Equatorial Shanghai

No.65, Yan An Road (West), Shanghai, 200040, China

中国上海市延安西路65号上海国际贵都大饭店办公楼 405 单元

Phone: +86-21-62489820

Fax: +86-21-62489821 
(C) 2012 The Author(s). Licensee IntechOpen. This is an open access article distributed under the terms of the Creative Commons Attribution 3.0 License, which permits unrestricted use, distribution, and reproduction in any medium, provided the original work is properly cited. 